Datum primitka članka u uredništvo: 31.3.2021.

Datum slanja članka na recenziju: 20.4. 2021.

Datum prihvaćanja članka za objavu: 11. 6.2021.

Doc. dr. sc. Berislav Žmuk *

Izv. prof. dr. sc. Hrvoje Jošić ${ }^{* *}$

\title{
GODINA DANA BOLESTI COVID-19 U REPUBLICI HRVATSKOJ: POGLED S KVANTITATIVNE PERSPEKTIVE
}

\section{ONE YEAR OF COVID-19 IN THE REPUBLIC OF CROATIA: A VIEW FROM A QUANTITATIVE PERSPECTIVE}

SAŽETAK: Bolest COVID-19 visoko je zarazna bolest čiji je uzročnik takozvani koronavirus. Uzročnik bolesti, virus SARS-CoV-2, prvi put je otkriven krajem 2019. godine u gradu Wuhanu u kineskoj provinciji Hubei. Odatle se velikom brzinom proširio diljem svijeta uzrokujući svjetsku pandemiju bolesti COVID-19. U Hrvatskoj je prvi slučaj zaraze potvrđen 25. veljače 2020. godine. U radu se opisuje kretanje broja zaraženih, broja umrlih te broja aktivnih odnosno izliječenih osoba od bolesti COVID-19 u Republici Hrvatskoj u razdoblju od 25. veljače 2020. godine do 25. veljače 2021. godine. U radu se također prikazuje i kretanje vrijednosti varijabli povezanih s bolesti COVID-19 na razini županija Republike Hrvatske. Ovaj rad predstavlja temelj za buduća statistička modeliranja vezano za kretanje COVID-19 varijabli, a što bi trebalo rezultirati rješenjima za obuzdavanje navedene pandemije.

KLJUČNE RIJEČI: broj zaraženih, COVID-19, Hrvatska, koronavirus, SARSCoV-2.

JEL: C10.

ABSTRACT: COVID-19 is a highly contagious disease caused by the so-called coronavirus. The causative agent of the disease, the SARS-CoV-2 virus, was firstly discovered in the late 2019 in the city of Wuhan, in the Chinese province of Hubei. From there, it spread rapidly around the world causing a worldwide pandemic of COVID-19 disease. In Croatia, the first case of infection was confirmed on February 25, 2020. This paper describes the movement of the number of infected, the number of deaths and the number of active and

Doc. dr. sc. Berislav Žmuk, Ekonomski fakultet Sveučilišta u Zagrebu, Trg J. F. Kennedyja 6, 10000 Zagreb,Hrvatska, e-mail: bzmuk@efzg.hr

** Izv. prof. dr. sc. Hrvoje Jošić, Ekonomski fakultet Sveučilišta u Zagrebu, Trg J. F. Kennedyja 6, 10000 Zagreb, Hrvatska, e-mail: hjosic@efzg.hr 
cured persons from COVID-19 disease in the Republic of Croatia in the period from 25 February 2020 to 25 February 2021. The paper also presents the movement of the values of variables associated with COVID-19 disease at the county level in the Republic of Croatia. This paper provides the basis for future statistical modelling related to the movement of COVID-19 variables, which should result in solutions to curb this pandemic.

KEY WORDS: number of infected, COVID-19, Croatia, coronavirus, SARS-CoV-2. JEL: C10.

\section{UVOD}

Nakon svjetske pandemije virusa H1N1 (poznat i pod nazivom virus svinjske gripe) u 2009. godini (Fineberg, 2014), krajem 2019. godine započela je nova svjetska pandemija. Ovaj put je za pandemiju odgovoran SARS-CoV-2, virus koji uzrokuje bolest naziva COVID-19 (Yuen et al., 2020). Već krajem jeseni 2019. godine liječnici u gradu Wuhanu, provincija Hubei, Kina, izvijestili su da se kod pacijenata pojavila virusna upala pluća nepoznata podrijetla. Uz to, uočena je i pojava simptoma poput malaksalosti, vrućice, dispneje (otežano disanje) i suhog kašlja (Janik et al., 2021). Uslijed veoma brzog širenja bolesti diljem svijeta, Svjetska zdravstvena organizacija (the World Health Organization) je 11. ožujka 2020. godine proglasila pandemiju bolesti uzrokovane virusom SARS-CoV-2 (engl. $S A R S$ - severe acute respiratory syndrome - teški akutni respiratorni sindrom) te ju je nazvala koronavirusna bolest 2019 (kraće COVID-19) (Hiscott et al., 2020).

Koronavirusi pripadaju skupini zoonotskih virusa, odnosno mogu se prenositi između životinja i ljudi (de Oliveira Lima, 2020). Virus SARS-CoV-2 uobičajeno uzrokuje respiratorne i gastrointestinalne bolesti kod životinja i ljudi, a daljnjim istraživanjem se pokazalo da su simptomi bolesti COVID-19 sljedeći: visoka temperatura, hladnoća, kašalj, kratkoća daha, otežano disanje, proljev, umor, mialgija (bol u mišićima), hemoptiza (iskašljavanje krvi iz dišnog sustava), glavobolja, gubitak osjeta mirisa i okusa, osip, bol u prsima, gubitak govora, nemogućnost kretanja (Pal et al., 2020, World Health Organization, 2021a). Bolest COVID-19 može rezultirati smrtnim ishodom zaražene osobe, dok osobe koje su preboljele ovu bolest mogu imati dugoročne posljedice. Pokazalo se da se pojavljuju određene disfunkcije na glavnim organima poput srca, pluća i mozga. Uz to, pojavljuje se zabrinutost liječnika vezano uz emocionalno zdravlje oboljelih (del Rio, Collins, Malani, 2020).

Dakako, uza sve navedeno pojavljuje se i zabrinutost za ekonomsko blagostanje stanovništva uslijed činjenice da su diljem svijeta, a u svrhu zaustavljanja daljnjeg širenja bolesti COVID-19, donijete različite mjere koje su ograničile ili u potpunosti zaustavile ekonomsku aktivnost u značajnom broju ekonomskih djelatnosti (Deb et al., 2020). Tako je i Hrvatska poduzela određene mjere kojima je prvi cilj bio očuvanje zdravlja stanovništva, a potom i očuvanje razine gospodarske djelatnosti (Tadić, 2020). Krajem 2020. godine pojavila su se prva cjepiva protiv bolesti COVID-19 (World Health Organization, 2021b). Međutim, kako bi se uspješno suzbila pandemija bolesti COVID-19 potrebno je procijepiti oko $70 \%$ stanovništva (Janik, 2021). Dodatni je problem što cjepiva još uvijek nisu dostupna u potrebnim količinama (Wouters et al., 2021). Dakako, postoji još cijeli niz pitanja vezan za cjepiva protiv bolesti COVID-19 (Forni, Mantovani, 2021). Stoga će biti potrebno i nadalje 
boriti se protiv ove bolesti određenim mjerama poput ograničavanja kretanja stanovništva i ostalim ekonomskim mjerama. Budući da je prošlo više od godine dana u razdoblju u kojem se svijet nalazi pod pandemijom ove bolesti, moguće je procijeniti kvalitetu i uspješnost donesenih mjera i odluka usmjerenih na zaštitu zdravlja stanovništva i očuvanje ekonomske aktivnosti.

Sukladno tome, cilj ovog rada je pružiti podlogu za buduća statistička modeliranja kretanja broja oboljelih od bolesti COVID-19, uvid u razmjere širenja bolesti te preispitati učinkovitost određenih ekonomskih mjera. Rad će se usredotočiti na pregled broja slučajeva zaraženih osoba u Hrvatskoj u jednogodišnjem razdoblju, od prvog dana zabilježenog slučaja bolesti COVID-19. Osim broja zaraženih promatrat će se i brojevi izliječenih te preminulih uslijed ove bolesti. Dodatno, pregled navedenih varijabli bit će dan na razini Hrvatske u cjelini, ali će se promatrati i situacija vezano za navedene varijable i na razini županija. Rad je koncipiran kako slijedi. Nakon kratkog uvoda u problematiku istraživanja u prvom poglavlju, u drugom poglavlju se daje pregled korištene metodologije, opisuju se promatrane varijable te se navode izvori podataka. U trećem poglavlju sadržani su rezultati istraživanja popraćeni odgovarajućom diskusijom. U četvrtom poglavlju iznose se zaključci rada te se daju preporuke za buduća istraživanja.

\section{PODACI I METODOLOGIJA}

U radu će se promatrati evidencija broja zaraženih bolešću COVID-19 u jednogodišnjem razdoblju, od 25. veljače 2020. godine do 25. veljače 2021. godine. Naime, na dan 25. veljače 2020. godine zabilježen je i potvrđen prvi slučaj zaraze bolesti COVID-19 u Hrvatskoj (Ministarstvo zdravstva, 2020). U analizi će se koristiti podaci preuzeti sa službene stranice Vlade Republike Hrvatske za pravodobne i točne informacije o koronavirusu (Koronavirus.hr, 2021a-c). U tablici 1 prikazan je popis COVID-19 varijabli koje će biti predmet razmatranja s istaknutim vremenskim razdobljima promatranja.

Tablica 1. Popis COVID-19 varijabli

\begin{tabular}{|c|l|c|c|}
\hline $\begin{array}{c}\text { Redni } \\
\text { broj }\end{array}$ & \multicolumn{1}{|c|}{ Naziv varijable } & $\begin{array}{c}\text { Razina } \\
\text { promatranja }\end{array}$ & Razdoblje promatranja \\
\hline 1. & Ukupan broj slučajeva & Hrvatska & $25.02 .2020 .-25.02 .2021$. \\
\hline 2. & Ukupan broj slučajeva & Županije & $21.03 .2020 .-25.02 .2021$. \\
\hline 3. & Ukupan broj umrlih & Hrvatska & $25.02 .2020 .-25.02 .2021$. \\
\hline 4. & Ukupan broj umrlih & Županije & $21.03 .2020 .-25.02 .2021$. \\
\hline 5. & Broj aktivnih slučajeva & Hrvatska & $25.02 .2020 .-25.02 .2021$. \\
\hline 6. & Broj aktivnih slučajeva & Županije & $21.03 .2020 .-25.02 .2021$. \\
\hline 7. & Spol zaraženih & Hrvatska & $01.03 .2020 .-25.02 .2021$. \\
\hline 8. & Spol zaraženih & Županije & $01.03 .2020 .-25.02 .2021$. \\
\hline 9. & Godina rođenja zaraženih & Hrvatska & $01.03 .2020 .-25.02 .2021$. \\
\hline 10. & Godina rođenja zaraženih & Županije & $01.03 .2020 .-25.02 .2021$. \\
\hline
\end{tabular}

Izvor: izrada autora. 
Premda se nastojalo osigurati podatke za sve varijable za cijelo promatrano jednogodišnje razdoblje od 25 . veljače 2020. godine do 25 . veljače 2021. godine, to nažalost nije bilo moguće napraviti zbog ograničenja korištene baze podataka. Dodatno je bilo određenih problema s nedostajućim podacima. Tako nedostaju podaci za varijable ukupan broj zaraženih, ukupan broj umrlih te ukupan broj aktivnih slučajeva na razini svijeta za 27. ožujak 2020. godine. Ti podaci su procijenjeni kao aritmetička sredina vrijednosti iz prethodnog i idućeg dana. Nedostaju i podaci o spolu, godini rođenja i županiji za ukupno 19 zaraženih osoba (tri osobe iz ožujka 2020. godine, osam osoba iz svibnja 2020. godine, te osam osoba iz lipnja 2020. godine). Nažalost, navedene informacije nije bilo moguće na nikakav način rekonstruirati ili procijeniti. Stoga će biti određenih razlika u vrijednostima zaraženih osoba među različitim analizama.

Budući da ovaj rad predstavlja podlogu za buduća detaljnija statistička i ekonomska istraživanja, u radu se primjenjuju osnovne metode deskriptivne statistike. Na taj će način najvažnije karakteristike bolesti COVID-19 i njihovi trendovi promjena vrijednosti biti prikazani na jasan i uočljiv način.

\section{REZULTATI ISTRAŽIVANJA I DISKUSIJA}

\subsection{Analiza pandemije bolesti COVID-19 u Hrvatskoj}

Od prvog potvrđenog slučaja bolesti COVID-19 od 25. veljače 2020. godine broj slučajeva skoro neprestano raste. Ipak, bilo je nekoliko dana u kojima nije bio zabilježen ni jedan novi slučaj bolesti COVID-19. To su bili dani na samom početku pandemije u Hrvatskoj (27. veljače 2020. godine, 3., 5. i 8. ožujka 2020. godine) te na kraju svibnja i početkom lipnja 2020. godine kada je u razdoblju od 22. svibnja do 11. lipnja 2020. godine bilo evidentirano samo šest novih slučajeva bolesti COVID-19. Ukupan broj evidentiranih slučajeva bolesti COVID-19 u Hrvatskoj u cijelom razdoblju promatranja od 25. veljače 2020. godine do 25 . veljače 2021. godine prikazan je na slici 1 .

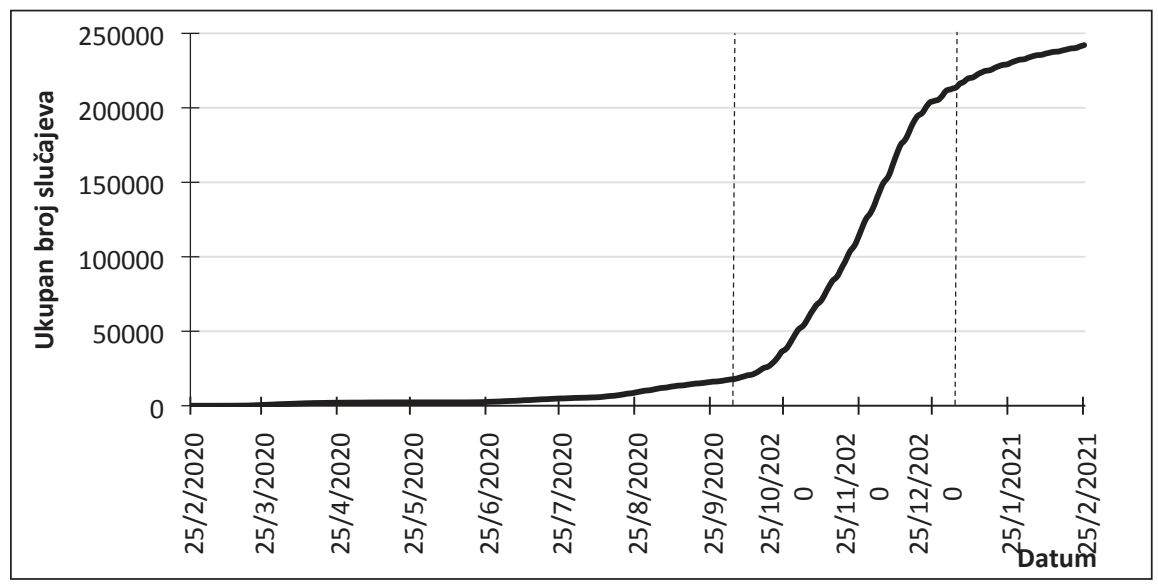

Slika 1. Ukupan broj slučajeva bolesti COVID-19 u Hrvatskoj u razdoblju od 25. veljače 2020. godine do 25. veljače 2021. godine

Izvor: izrada autora. 
Prema slici 1, uočavaju se tri razdoblja u kretanju broja slučajeva bolesti COVID-19 u Hrvatskoj. U prvom razdoblju broj slučajeva bolesti COVID-19 raste, ali blago i linearno. U drugom razdoblju broj slučajeva bolesti COVID-19 počinje snažno, gotovo pa eksponencijalno, rasti. U posljednjem, trećem razdoblju broj slučajeva bolesti COVID-19 nastavlja dalje rasti, ali, za razliku od drugog razdoblja, po daleko manjim stopama. Prema krivulji prikazanoj na slici 1 i praktičnosti uzet će se da prvo razdoblje obuhvaća period od 25. veljače do 30. rujna 2020. godine, drugo razdoblje pokriva period od 1. listopada do 31. prosinca 2020. godine, dok treće razdoblje obuhvaća period od 1. siječnja pa sve do 25 . veljače 2021. godine. Navedena podjela po razdobljima, radi lakšeg praćenja i usporedbe ostalih promatranih COVID-19 varijabli, koristit će se i u nastavku analize.

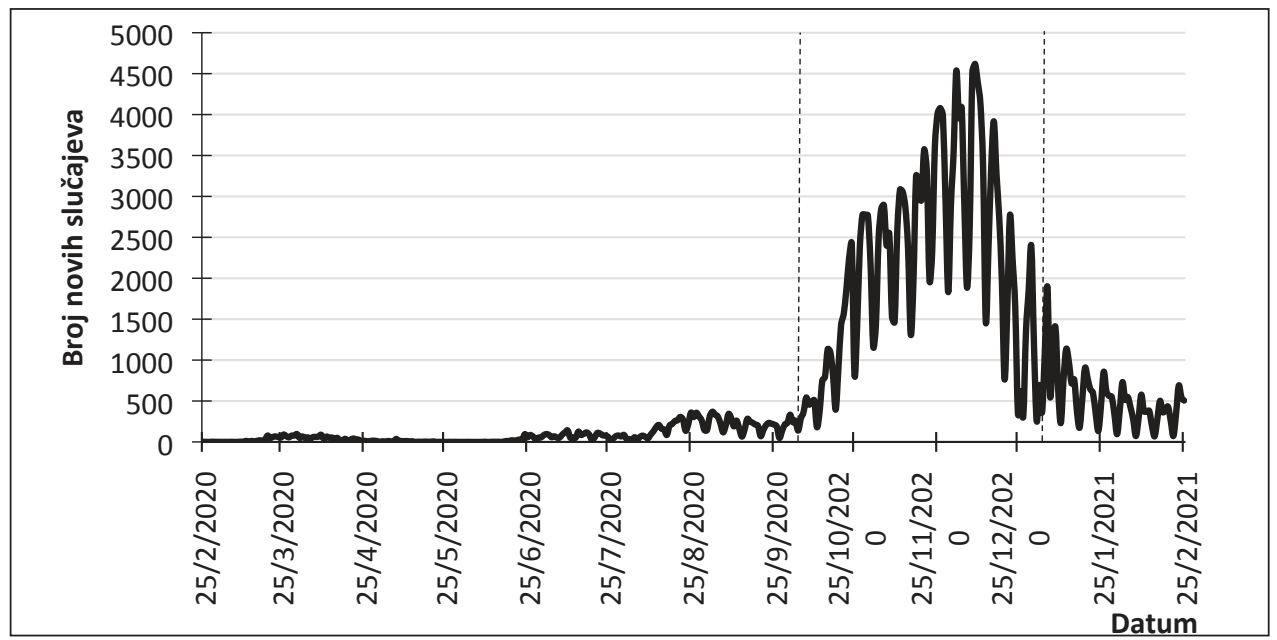

Slika 2. Broj novih slučajeva bolesti COVID-19 u Hrvatskoj u razdoblju od 25. veljače 2020. godine do 25. veljače 2021. godine

Izvor: izrada autora.

Na slici 2 prikazan je broj novoevidentiranih slučajeva bolesti COVID-19 u Hrvatskoj u promatranom jednogodišnjem razdoblju. Za razliku od krivulje sa slike 1, krivulja sa slike 2 nije toliko glatka. Naime, nedjeljom se redovito provodi manje testiranja, što, posljedično, rezultira s manjim brojem novoevidentiranih slučajeva bolesti COVID-19. 

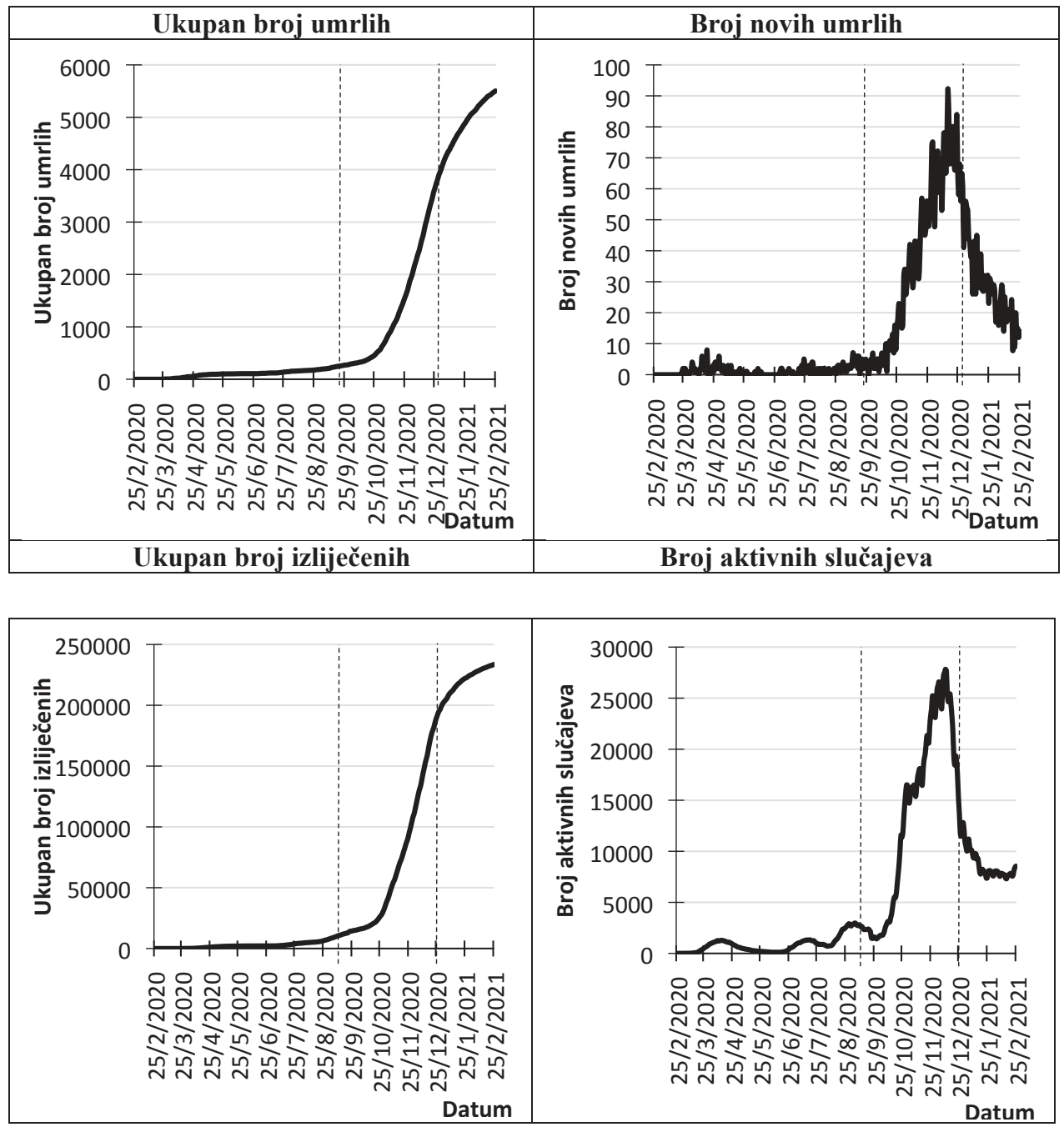

Slika 3. Vrijednosti broja umrlih, izliječenih i broja aktivnih slučajeva bolesti COVID-19 u Hrvatskoj u razdoblju od 25. veljače 2020. godine do 25 . veljače 2021. godine

Izvor: izrada autora.

Na slici 3 prikazano je kretanje broja umrlih, izliječenih i broja aktivnih slučajeva bolesti COVID-19 u Hrvatskoj u razdoblju od 25. veljače 2020. godine do 25. veljače 2021. godine. Trendovi kretanja kod ovih varijabli identični su kretanjima COVID-19 varijabli vezanih uz ukupan broj slučajeva COVID-19 te broj novih slučajeva bolesti COVID-19. 
B. Žmuk, H. Jošić: Godina dana bolesti COVID-19 u Republici Hrvatskoj: pogled s kvantitativne...

Tablica 2. Odabrani deskriptivno-statistički pokazatelji analize COVID-19 varijabli na razini Republike Hrvatske

\begin{tabular}{|c|c|c|c|c|c|c|c|}
\hline \multirow[b]{2}{*}{$\begin{array}{c}\text { COVID-19 } \\
\text { varijabla }\end{array}$} & \multicolumn{7}{|c|}{ Pokazatelji } \\
\hline & $\begin{array}{l}\text { Broj } \\
\text { dana }\end{array}$ & $\begin{array}{c}\text { Aritm. } \\
\text { sredina }\end{array}$ & Medijan & $\begin{array}{c}\text { Stand. } \\
\text { dev. }\end{array}$ & $\begin{array}{l}\text { Koef. } \\
\text { var. }\end{array}$ & $\begin{array}{c}\text { Najmanja } \\
\text { vrijed. }\end{array}$ & $\begin{array}{c}\text { Najveća } \\
\text { vrijed. }\end{array}$ \\
\hline \multicolumn{8}{|c|}{ Od 25.02.2020. do 25.02.2021. } \\
\hline $\begin{array}{l}\text { Ukupan broj } \\
\text { slučajeva }\end{array}$ & 367 & 62.712 & 9.192 & 88.148 & $141 \%$ & 2 & 242.097 \\
\hline Broj novih slučajeva & 367 & 660 & 145 & 1.071 & $162 \%$ & 0 & 4.620 \\
\hline Ukupan broj umrlih & 367 & 1.187 & 177 & 1.790 & $151 \%$ & 0 & 5.503 \\
\hline Broj novih umrlih & 367 & 15 & 3 & 22 & $147 \%$ & 0 & 92 \\
\hline $\begin{array}{l}\text { Ukupan broj } \\
\text { izliječenih }\end{array}$ & 367 & 56.925 & 6.595 & 83.566 & $147 \%$ & 0 & 233.548 \\
\hline $\begin{array}{l}\text { Broj aktivnih } \\
\text { slučajeva }\end{array}$ & 367 & 5.786 & 1.609 & 7.481 & $129 \%$ & 2 & 27.832 \\
\hline \multicolumn{8}{|c|}{ Od 25.02.2020. do 30.09.2020. } \\
\hline $\begin{array}{l}\text { Ukupan broj } \\
\text { slučajeva }\end{array}$ & 219 & 4.424 & 2.252 & 4.468 & $101 \%$ & 2 & 16.827 \\
\hline Broj novih slučajeva & 219 & 77 & 50 & 91 & $119 \%$ & 0 & 369 \\
\hline Ukupan broj umrlih & 219 & 106 & 107 & 74 & $70 \%$ & 0 & 284 \\
\hline Broj novih umrlih & 219 & 1 & 1 & 2 & $123 \%$ & 0 & 8 \\
\hline $\begin{array}{l}\text { Ukupan broj } \\
\text { izliječenih }\end{array}$ & 219 & 3.471 & 2.134 & 3.838 & $111 \%$ & 0 & 15.218 \\
\hline $\begin{array}{l}\text { Broj aktivnih } \\
\text { slučajeva }\end{array}$ & 219 & 953 & 840 & 826 & $87 \%$ & 2 & 2.968 \\
\hline \multicolumn{8}{|c|}{ Od 01.10.2020. do 31.12.2020. } \\
\hline $\begin{array}{l}\text { Ukupan broj } \\
\text { slučajeva }\end{array}$ & 92 & 99.621 & 86.492 & 66.460 & $67 \%$ & 17.160 & 212.007 \\
\hline Broj novih slučajeva & 92 & 2.122 & 2.238 & 1.238 & $58 \%$ & 138 & 4.620 \\
\hline Ukupan broj umrlih & 92 & 1.495 & 1.098 & 1.162 & $78 \%$ & 291 & 3.961 \\
\hline Broj novih umrlih & 92 & 40 & 42 & 26 & $66 \%$ & 1 & 92 \\
\hline $\begin{array}{l}\text { Ukupan broj } \\
\text { izliječenih }\end{array}$ & 92 & 83.946 & 69.859 & 61.125 & $73 \%$ & 15.423 & 199.820 \\
\hline $\begin{array}{l}\text { Broj aktivnih } \\
\text { slučajeva }\end{array}$ & 92 & 15.674 & 16.464 & 7.956 & $51 \%$ & 1.737 & 27.832 \\
\hline \multicolumn{8}{|c|}{ Od 01.01. 2021. do 25.02. 2021} \\
\hline $\begin{array}{l}\text { Ukupan broj } \\
\text { slučajeva }\end{array}$ & 56 & 230.021 & 231.815 & 8.355 & $4 \%$ & 212.262 & 242.097 \\
\hline Broj novih slučajeva & 56 & 537 & 504 & 337 & $63 \%$ & 68 & 1.896 \\
\hline Ukupan broj umrlih & 56 & 4.910 & 4.985 & 429 & $9 \%$ & 4.016 & 5.503 \\
\hline Broj novih umrlih & 56 & 28 & 27 & 12 & $42 \%$ & 8 & 56 \\
\hline $\begin{array}{l}\text { Ukupan broj } \\
\text { izliječenih }\end{array}$ & 56 & 221.578 & 223.734 & 9.242 & $4 \%$ & 201.300 & 233.548 \\
\hline $\begin{array}{l}\text { Broj aktivnih } \\
\text { slučajeva }\end{array}$ & 56 & 8.443 & 8.040 & 1.029 & $12 \%$ & 7.316 & 11.208 \\
\hline
\end{tabular}

Izvor: izrada autora. 
Kako bi se nadopunila grafička analiza, u tablici 2 dane su vrijednosti odabranih statističkih pokazatelja za promatrane COVID-19 varijable u cjelokupnom promatranom razdoblju te za svako izdvojeno razdoblje zasebno. Ukoliko se promatraju rezultati u cjelini, primjećuje se prisutnost visoke razine varijabilnosti kod svih COVID-19 varijabli. Promatranje varijabli zasebno po razdobljima smanjilo je razinu varijabilnosti, što potvrđuje ispravnost odluke o promatranju izdvojenih razdoblja. Prvo razdoblje, od 25. veljače do 30 . rujna 2020. godine, karakteriziraju izuzetno niske razine broja slučajeva i broja umrlih od bolesti COVID-19. Za razliku od tog razdoblja, u drugom razdoblju, od 1. listopada do 31 . prosinca 2020. godine, zabilježeni su izuzetno visoki brojevi zaraženih i umrlih osoba od bolesti COVID-19. U trećem razdoblju, od 1. siječnja do 25. veljače 2021. godine, brojevi zaraženih i umrlih od bolesti COVID-19 još su uvijek visoki, ali ipak značajno manji u odnosu na vrijednosti iz drugog razdoblja.

\subsection{Analiza pandemije bolesti COVID-19 po županijama u Hrvatskoj}

U ovom potpoglavlju promatrat će se razine broja aktivnih slučajeva, ukupan broj umrlih i ukupan broj slučajeva bolesti COVID-19 na razini županija Republike Hrvatske. Zbog ograničenosti prostora, na slici 4 prikazane su samo vrijednosti broja aktivnih slučajeva bolesti COVID-19 po županijama u razdoblju od 21. ožujka 2020. godine do 25. veljače 2021. godine. Analogno prikazima sa slike 4 mogli bi se napraviti grafički prikazi i za preostale dvije COVID-19 varijable na razini županija.

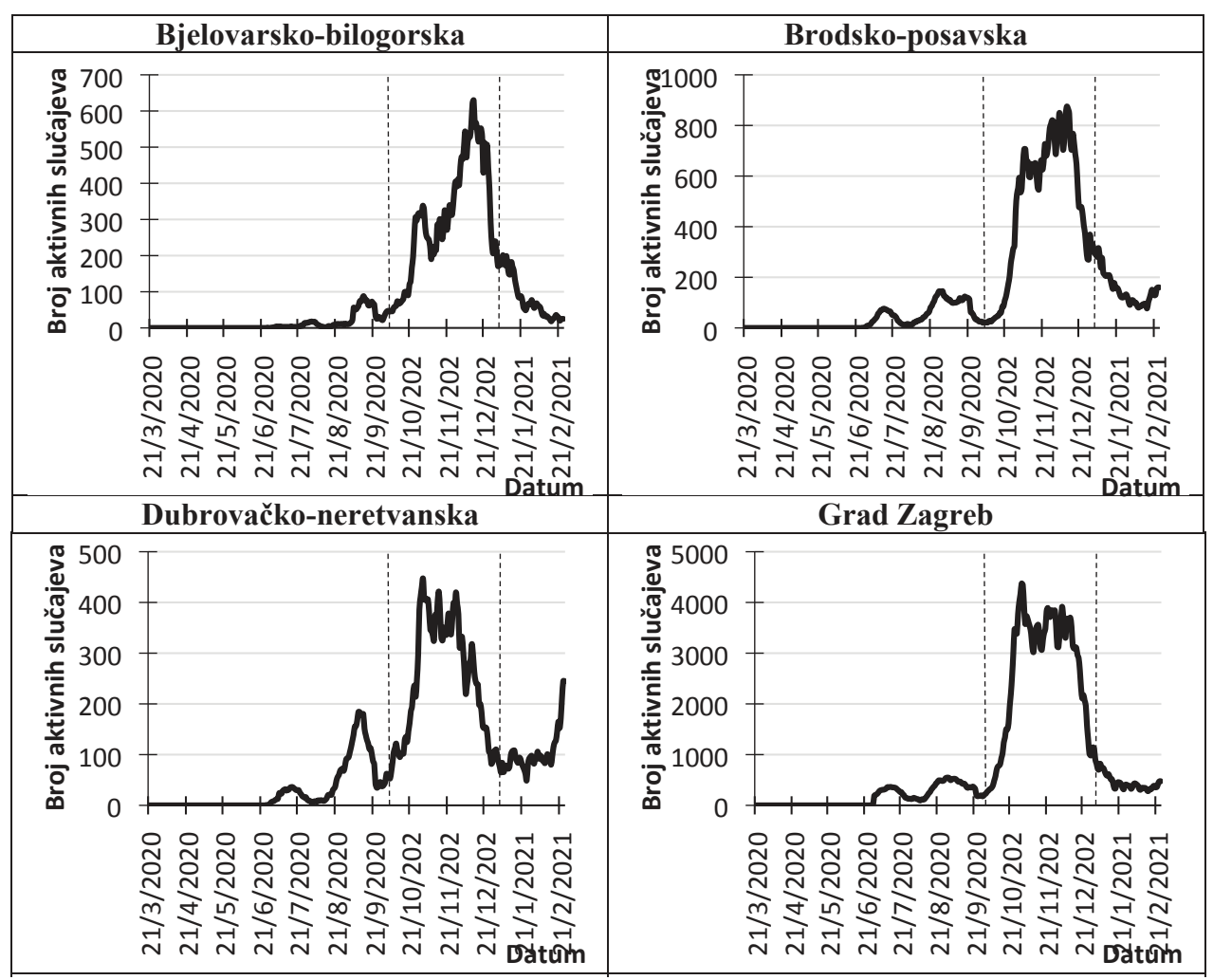




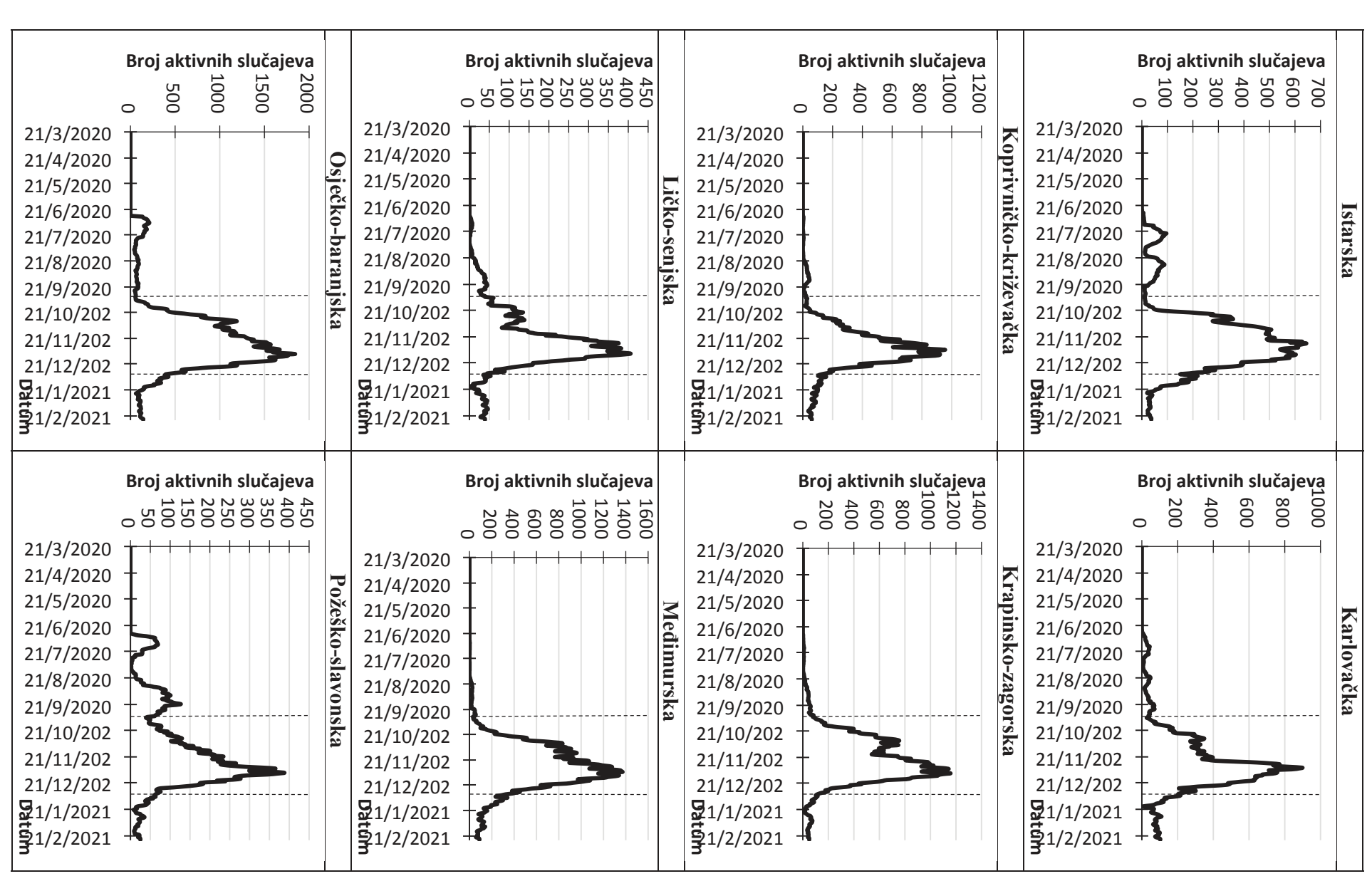




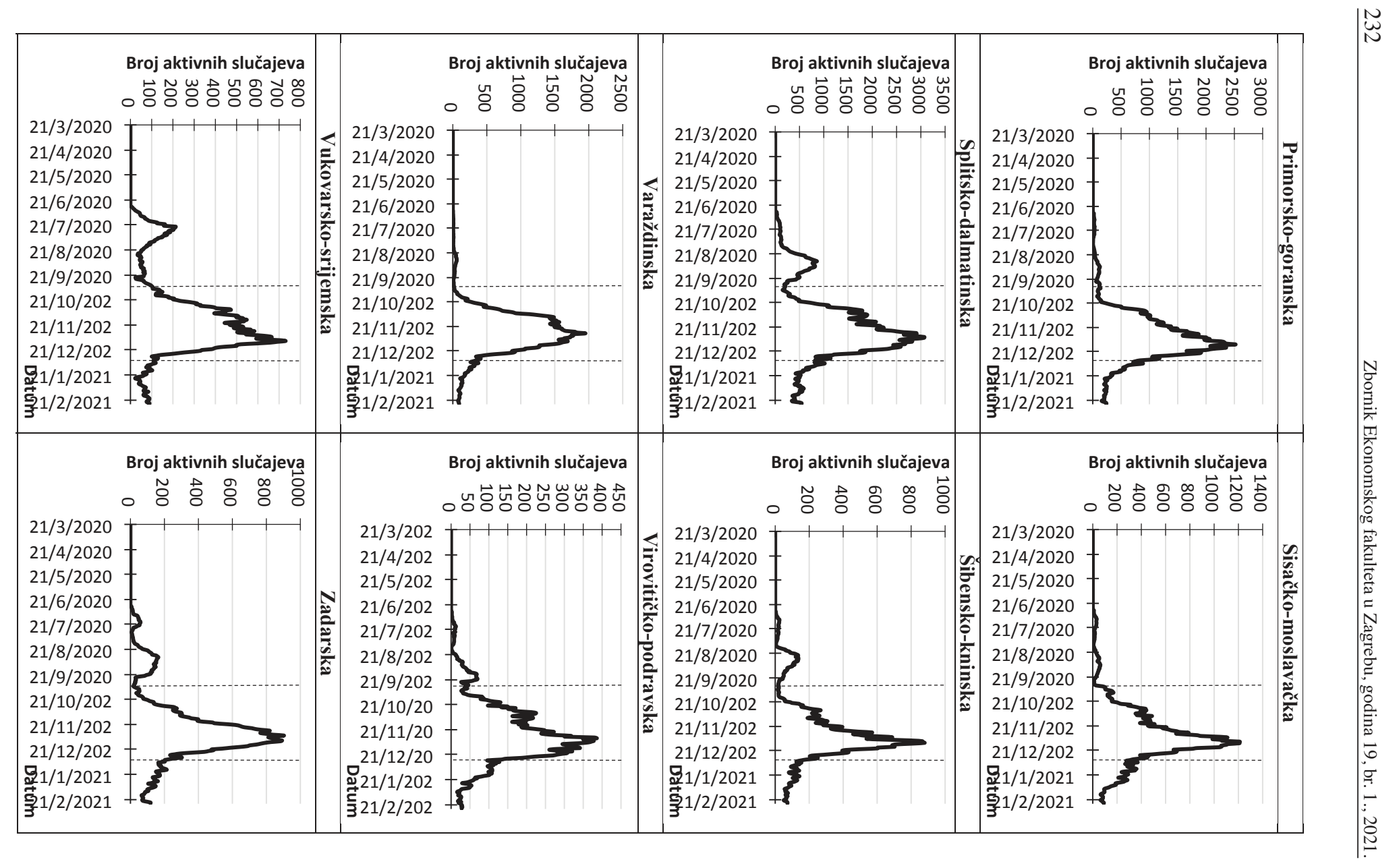




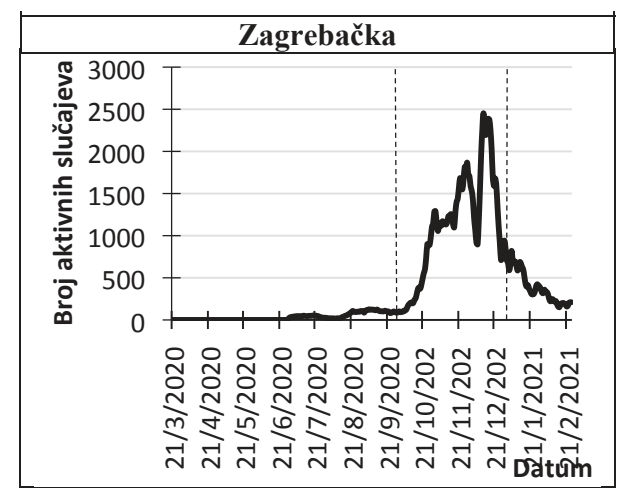

Slika 4. Vrijednosti broja aktivnih slučajeva bolesti COVID-19 po županijama u razdoblju od 21. ožujka 2020. godine do 25. veljače 2021. godine

Izvor: izrada autora.

Slika 4 otkriva kako je podjela jednogodišnjeg promatranog razdoblja na tri razdoblja također opravdana i na razini županija. Naime, kod svake županije pokazalo se postojanje prvog razdoblja s niskom razinom broja aktivnih slučajeva bolesti COVID-19, da bi potom uslijedilo razdoblje s izuzetno visokim razinama broja aktivnih slučajeva bolesti COVID-19, da bi nakon toga uslijedio pad. Međutim, kod određenih županija, poput Dubrovačko-neretvanske i Vukovarsko-srijemske županije, postoje takozvani šiljci, odnosno periodi u kojima su zabilježene visoke razine broja aktivnih slučajeva bolesti COVID-19 i u prvom razdoblju (od 21. ožujka do 30. rujna 2020. godine).

Tablica 3. Broj aktivnih slučajeva (najveća vrijednost u promatranom razdoblju), ukupan broj umrlih (vrijednost na kraju razdoblja) i ukupan broj slučajeva (vrijednost na kraju razdoblja) bolesti COVID-19 na razini županija

\begin{tabular}{|c|c|c|c|c|c|c|c|c|c|}
\hline \multirow{3}{*}{ Županija } & \multicolumn{9}{|c|}{ Razdoblje } \\
\hline & \multicolumn{3}{|c|}{$\begin{array}{c}\text { Od 21. 03. 2020. do 30. } 09 . \\
2020 .\end{array}$} & \multicolumn{3}{|c|}{$\begin{array}{l}\text { Od } 01.10 .2020 \text {. do } 31.12 . \\
2020 .\end{array}$} & \multicolumn{3}{|c|}{$\begin{array}{l}\text { Od 01.01. 2021. do } 25.02 . \\
2021 .\end{array}$} \\
\hline & $\begin{array}{c}\text { Broj } \\
\text { aktivnih } \\
\text { slučaj. }\end{array}$ & $\begin{array}{c}\text { Ukupan } \\
\text { broj } \\
\text { umrlih }\end{array}$ & 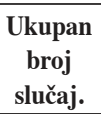 & $\begin{array}{c}\text { Broj } \\
\text { aktivnih } \\
\text { slučaj. }\end{array}$ & \begin{tabular}{c|}
$\begin{array}{c}\text { Ukupan } \\
\text { broj } \\
\text { umrlih }\end{array}$ \\
\end{tabular} & $\begin{array}{c}\text { Ukupan } \\
\text { broj } \\
\text { slučaj. }\end{array}$ & $\begin{array}{c}\text { Broj } \\
\text { aktivnih } \\
\text { slučaj. }\end{array}$ & $\begin{array}{c}\text { Ukupan } \\
\text { broj } \\
\text { umrlih }\end{array}$ & $\begin{array}{c}\text { Ukupan } \\
\text { broj } \\
\text { slučaj. }\end{array}$ \\
\hline Bjelovarsko-bilogorska & 88 & 1 & 250 & 629 & 72 & 4.858 & 206 & 132 & 5.638 \\
\hline Brodsko-posavska & 145 & 5 & 633 & 874 & 77 & 7.051 & 333 & 123 & 8.331 \\
\hline Dubrovačko-neretvanska & 184 & 14 & 660 & 447 & 61 & 4.140 & 245 & 75 & 5.095 \\
\hline Grad Zagreb & 547 & 56 & 3.496 & 4.373 & 1.159 & 41.260 & 900 & 1.705 & 45.773 \\
\hline Istarska & 96 & 12 & 476 & 643 & 54 & 5.575 & 219 & 78 & 6.179 \\
\hline Karlovačka & 71 & 2 & 352 & 897 & 193 & 5.819 & 228 & 252 & 6.679 \\
\hline Koprivničko-križevačka & 45 & 16 & 224 & 956 & 129 & 5.389 & 157 & 182 & 6.119 \\
\hline Krapinsko-zagorska & 64 & 2 & 382 & 1.155 & 221 & 8.483 & 148 & 290 & 9.086 \\
\hline Ličko-senjska & 45 & 1 & 180 & 406 & 74 & 2.510 & 65 & 94 & 2.791 \\
\hline Međimurska & 56 & 0 & 162 & 1.370 & 133 & 9.343 & 339 & 156 & 10.568 \\
\hline
\end{tabular}




\begin{tabular}{|c|c|c|c|c|c|c|c|c|c|}
\hline \multirow{3}{*}{ Županija } & \multicolumn{9}{|c|}{ Razdoblje } \\
\hline & \multicolumn{3}{|c|}{$\begin{array}{c}\text { Od 21. 03. } 2020 . \text { do } 30.09 . \\
2020 .\end{array}$} & \multicolumn{3}{|c|}{$\begin{array}{c}\text { Od 01. 10. 2020. do } 31.12 . \\
2020 .\end{array}$} & \multicolumn{3}{|c|}{$\begin{array}{c}\text { Od 01. 01. 2021. do } 25.02 . \\
2021 .\end{array}$} \\
\hline & $\begin{array}{c}\text { Broj } \\
\text { aktivnih } \\
\text { slučaj. }\end{array}$ & \begin{tabular}{|c|}
$\begin{array}{c}\text { Ukupan } \\
\text { broj } \\
\text { umrlih }\end{array}$ \\
\end{tabular} & $\begin{array}{c}\text { Ukupan } \\
\text { broj } \\
\text { slučaj. }\end{array}$ & $\begin{array}{c}\text { Broj } \\
\text { aktivnih } \\
\text { slučaj. }\end{array}$ & 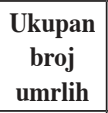 & $\begin{array}{c}\text { Ukupan } \\
\text { broj } \\
\text { slučaj. }\end{array}$ & \begin{tabular}{|c|} 
Broj \\
aktivnih \\
slučaj.
\end{tabular} & \begin{tabular}{|c|} 
Ukupan \\
broj \\
umrlih
\end{tabular} & $\begin{array}{c}\begin{array}{c}\text { Ukupan } \\
\text { broj }\end{array} \\
\text { slučaj. }\end{array}$ \\
\hline Osječko-baranjska & 211 & 39 & 1.026 & \begin{tabular}{|l|}
1.844 \\
\end{tabular} & 504 & 14.371 & 466 & 671 & 15.861 \\
\hline Požeško-slavonska & 127 & 1 & 426 & 388 & 58 & 2.510 & 70 & 84 & 2.796 \\
\hline Primorsko-goranska & 127 & 10 & 667 & 2.517 & 182 & 15.350 & 888 & 243 & 17.770 \\
\hline Sisačko-moslavačka & 63 & 2 & 282 & 1.210 & 112 & 7.581 & 369 & 113 & 9.110 \\
\hline Splitsko-dalmatinska & 859 & 76 & 3.986 & 3.071 & 322 & 25.982 & 1.014 & 439 & 30.482 \\
\hline Šibensko-kninska & 137 & 6 & 556 & 880 & 69 & 4.959 & 183 & 96 & 5.825 \\
\hline Varaždinska & 58 & 3 & 224 & 1.952 & 273 & 13.458 & 375 & 384 & 14.893 \\
\hline Virovitičko-podravska & 70 & 4 & 227 & 386 & 51 & 3.229 & 119 & 75 & 3.745 \\
\hline Vukovarsko-srijemska & 213 & 11 & 834 & 731 & 112 & 6.804 & 126 & 156 & 7.596 \\
\hline Zadarska & 164 & 9 & 748 & 904 & 95 & 6.826 & 257 & 131 & 8.029 \\
\hline Zagrebačka & 126 & 10 & 802 & 2.453 & 10 & 16.509 & 820 & 10 & 19.226 \\
\hline
\end{tabular}

Izvor: izrada autora.

U tablici 3 prikazan je broj aktivnih slučajeva (najveća vrijednost u promatranom razdoblju), ukupan broj umrlih (vrijednost na kraju razdoblja) te ukupan broj slučajeva (vrijednost na kraju razdoblja) bolesti COVID-19 za svaku županiju zasebno.

Tablica 4. Izdvojene županije s najmanjom i najvećom vrijednosti broja aktivnih slučajeva (najveća vrijednost u promatranom razdoblju), ukupnog broja umrlih (vrijednost na kraju razdoblja) i ukupnog broja slučajeva (vrijednost na kraju razdoblja) bolesti COVID-19

\begin{tabular}{|c|c|c|r|r|r|}
\hline \multirow{2}{*}{ Razdoblje } & \multirow{2}{*}{ COVID-19 varijabla } & \multicolumn{2}{|c|}{ Najmanja vrijednost } & \multicolumn{2}{c|}{ Najveća vrijednost } \\
\cline { 3 - 6 } & Broj aktivnih slučajeva & $\begin{array}{c}\text { Županija } \\
\text { Križevrivničko- } \\
\text { senjska Ličko- }\end{array}$ & 45 & $\begin{array}{c}\text { Zrijed. } \\
\text { Splitsko- } \\
\text { dalmatinska }\end{array}$ & 859 \\
\hline $\begin{array}{l}\text { Od 21.03.2020. } \\
\text { do 30.09.2020. }\end{array}$ & Ukupan broj umrlih & Međimurska & 0 & $\begin{array}{c}\text { Splitsko- } \\
\text { dalmatinska }\end{array}$ & 76 \\
\cline { 2 - 6 } & Ukupan broj slučajeva & Međimurska & 162 & $\begin{array}{c}\text { Splitsko- } \\
\text { dalmatinska }\end{array}$ & 3.986 \\
\hline \multirow{2}{*}{$\begin{array}{l}\text { Od 01.10.2020. } \\
\text { do 31.12.2020. }\end{array}$} & Broj aktivnih slučajeva & Virovitičko-podravska & 386 & Grad Zagreb & 4.373 \\
\cline { 2 - 6 } & Ukupan broj umrlih & Zagrebačka & 10 & Grad Zagreb & 1.159 \\
\hline \multirow{2}{*}{$\begin{array}{c}\text { Od 01.01.2021. } \\
\text { do 25.02.2021. }\end{array}$} & Broj aktivnih slučajeva & Ličko-senjska & 65 & $\begin{array}{c}\text { Splitsko- } \\
\text { dalmatinska }\end{array}$ & 1.014 \\
\cline { 2 - 6 } & Ukupan broj umrlih & Zagrebačka & 10 & Grad Zagreb & 1.705 \\
\cline { 2 - 6 } & Ukupan broj slučajeva & Ličko-senjska & 2.791 & Grad Zagreb & 45.773 \\
\hline
\end{tabular}

Izvor: izrada autora. 
Radi veće preglednosti, u tablici 4. izdvojene su županije kod kojih su zabilježene najniže odnosno najviše vrijednosti promatranih triju COVID-19 varijabli za sva tri izdvojena razdoblja. Prema tablici 4. najveće razine zaraženosti bolešću COVID-19 zabilježene su u Gradu Zagrebu i u Splitsko-dalmatinskoj županiji, što je bilo i očekivano jer navedena područja imaju ujedno i najviše stanovništva promatrano pojedinačno po županijama.

\subsection{Karakteristike zaraženih osoba u Hrvatskoj}

U nastavku analize promatrat će se karakteristike osoba koje su oboljele od bolesti COVID-19 u Hrvatskoj, promatrano na razini Hrvatske i na razini županija. Tako će se promatrati spol i godina rođenja zaraženih osoba. Na lici 5 prikazana je struktura osoba koje su oboljele od bolesti COVID-19 prema spolu na razini Hrvatske, i to za cjelokupno promatrano razdoblje te za svako od tri izdvojena razdoblja.

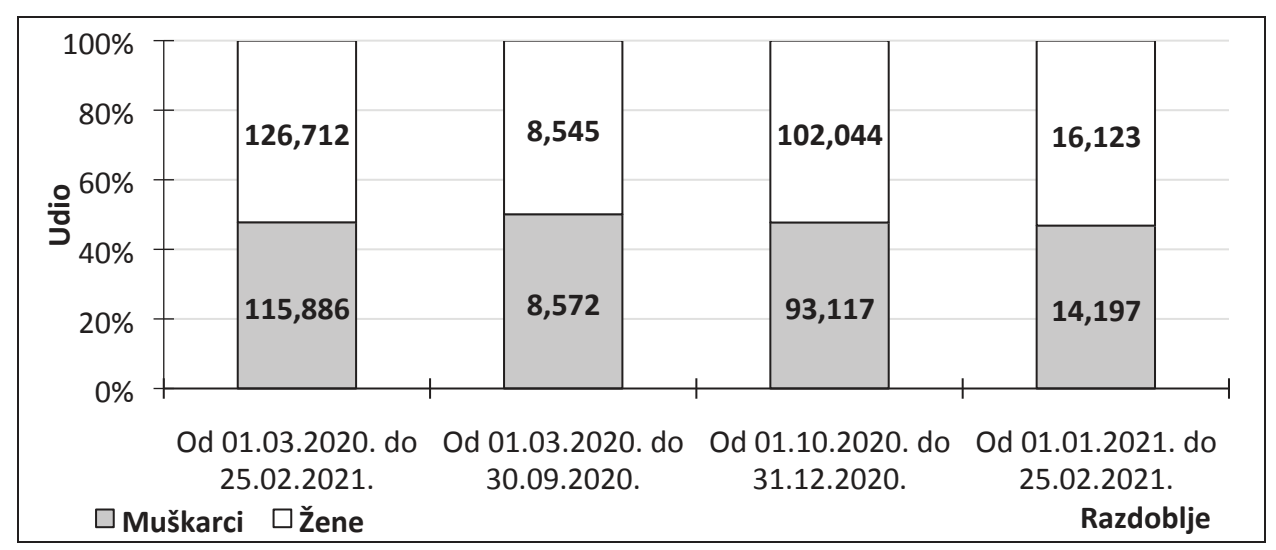

Slika 5. Struktura osoba koje su oboljele od bolesti COVID-19 prema spolu na razini Hrvatske, u razdoblju od 1. ožujka 2020. godine do 25. veljače 2021. godine

Izvor: izrada autora.

Prema slici 5. zaključuje se da je u svim razdobljima bolest COVID-19 otprilike jednako pogađala stanovništvo, odnosno u istom omjeru promatrano prema spolu. Tako je u prvom razdoblju, od 1. ožujka do 30. rujna 2020. godine, među oboljelima od bolesti COVID-19 bilo $50 \%$ žena. U drugom razdoblju, od 1. listopada do 31. prosinca 2020. godine, od ukupnog broja oboljelih od bolesti COVID-19 bilo je $52 \%$ žena, dok je u trećem razdoblju, od 1. siječnja do 25. veljače 2021., godine udio žena među oboljelim osobama od bolesti COVID-19 iznosio $53 \%$. 
Tablica 5. Struktura osoba koje su oboljele od bolesti COVID-19 prema spolu na razini županija, u razdoblju od 1. ožujka 2020. godine do 25. veljače 2021. godine

\begin{tabular}{|c|c|c|c|c|c|c|c|c|c|}
\hline \multirow{3}{*}{ Županija } & \multirow{3}{*}{ Mjera } & \multicolumn{8}{|c|}{ Razdoblje } \\
\hline & & \multicolumn{2}{|c|}{$\begin{array}{c}\text { Od } 01.03 . \\
\text { 2020. do } 25 . \\
\text { 02. } 2021 .\end{array}$} & \multicolumn{2}{|c|}{$\begin{array}{c}\text { Od 01.03. } \\
2020 . \text { do } 30 . \\
09.2020 .\end{array}$} & \multicolumn{2}{|c|}{\begin{tabular}{|c|} 
Od 01. 10. \\
2020. do 31. \\
12.2020. \\
\end{tabular}} & \multicolumn{2}{|c|}{$\begin{array}{c}\text { Od 01.01. } \\
\text { 2021. do } 25 \text {. } \\
\text { 02. } 2021 \text {. }\end{array}$} \\
\hline & & Mušk. & Žene & Mušk. & Žene & Mušk. & Žene & Mušk. & Žene \\
\hline \multirow{2}{*}{ Bjelovarsko-bilogorska } & Broj & 2.642 & 3.003 & 124 & 148 & 2.165 & 2.430 & 353 & 425 \\
\hline & $\%$ & $47 \%$ & $53 \%$ & $46 \%$ & $54 \%$ & $47 \%$ & $53 \%$ & $45 \%$ & $55 \%$ \\
\hline \multirow{2}{*}{ Brodsko-posavska } & Broj & 4.000 & 4.384 & 346 & 295 & 3.070 & 3.399 & 584 & 690 \\
\hline & $\%$ & $48 \%$ & $52 \%$ & $54 \%$ & $46 \%$ & $47 \%$ & $53 \%$ & $46 \%$ & $54 \%$ \\
\hline \multirow{2}{*}{ Dubrovačko-neretvanska } & Broj & 2.581 & 2.619 & 366 & 328 & 1.735 & 1.715 & 480 & 576 \\
\hline & $\%$ & $50 \%$ & $50 \%$ & $53 \%$ & $47 \%$ & $50 \%$ & $50 \%$ & $45 \%$ & $55 \%$ \\
\hline \multirow{2}{*}{ Grad Zagreb } & Broj & 22.039 & 23.882 & 1.889 & 1.682 & 18.056 & 19.647 & 2.094 & 2.553 \\
\hline & $\%$ & $48 \%$ & $52 \%$ & $53 \%$ & $47 \%$ & $48 \%$ & $52 \%$ & $45 \%$ & $55 \%$ \\
\hline \multirow{2}{*}{ Istarska } & Broj & 3.002 & 3.183 & 256 & 224 & 2.456 & 2.637 & 290 & 322 \\
\hline & $\%$ & $49 \%$ & $51 \%$ & $53 \%$ & $47 \%$ & $48 \%$ & $52 \%$ & $47 \%$ & $53 \%$ \\
\hline \multirow{2}{*}{ Karlovačka } & Broj & 3.275 & 3.433 & 194 & 179 & 2.666 & 2.780 & 415 & 474 \\
\hline & $\%$ & $49 \%$ & $51 \%$ & $52 \%$ & $48 \%$ & $49 \%$ & $51 \%$ & $47 \%$ & $53 \%$ \\
\hline \multirow{2}{*}{ Koprivničko-križevačka } & Broj & 2.869 & 3.276 & 95 & 139 & 2.418 & 2.742 & 356 & 395 \\
\hline & $\%$ & $47 \%$ & $53 \%$ & $41 \%$ & $59 \%$ & $47 \%$ & $53 \%$ & $47 \%$ & $53 \%$ \\
\hline \multirow{2}{*}{ Krapinsko-zagorska } & Broj & 4.411 & 4.694 & 188 & 235 & 3.933 & 4.154 & 290 & 305 \\
\hline & $\%$ & $48 \%$ & $52 \%$ & $44 \%$ & $56 \%$ & $49 \%$ & $51 \%$ & $49 \%$ & $51 \%$ \\
\hline \multirow{2}{*}{ Ličko-senjska } & Broj & 1.370 & 1.443 & 91 & 105 & 1.148 & 1.170 & 131 & 168 \\
\hline & $\%$ & $49 \%$ & $51 \%$ & $46 \%$ & $54 \%$ & $50 \%$ & $50 \%$ & $44 \%$ & $56 \%$ \\
\hline \multirow{2}{*}{ Međimurska } & Broj & 4.831 & 5.761 & 98 & 72 & 4.174 & 5.004 & 559 & 685 \\
\hline & $\%$ & $46 \%$ & $54 \%$ & $58 \%$ & $42 \%$ & $45 \%$ & $55 \%$ & $45 \%$ & $55 \%$ \\
\hline \multirow{2}{*}{ Osječko-baranjska } & Broj & 7.483 & 8.438 & 425 & 617 & 6.310 & 7.048 & 748 & 773 \\
\hline & $\%$ & $47 \%$ & $53 \%$ & $41 \%$ & $59 \%$ & $47 \%$ & $53 \%$ & $49 \%$ & $51 \%$ \\
\hline \multirow{2}{*}{ Požeško-slavonska } & Broj & 1.328 & 1.471 & 213 & 228 & 979 & 1.104 & 136 & 139 \\
\hline & $\%$ & $47 \%$ & $53 \%$ & $48 \%$ & $52 \%$ & $47 \%$ & $53 \%$ & $49 \%$ & $51 \%$ \\
\hline \multirow{2}{*}{ Primorsko-goranska } & Broj & 8.824 & 9.055 & 320 & 377 & 7.252 & 7.401 & 1.252 & 1.277 \\
\hline & $\%$ & $49 \%$ & $51 \%$ & $46 \%$ & $54 \%$ & $49 \%$ & $51 \%$ & $50 \%$ & $50 \%$ \\
\hline \multirow{2}{*}{ Sisačko-moslavačka } & Broj & 4.333 & 4.785 & 170 & 178 & 3.470 & 3.774 & 693 & 833 \\
\hline & $\%$ & $48 \%$ & $52 \%$ & $49 \%$ & $51 \%$ & $48 \%$ & $52 \%$ & $45 \%$ & $55 \%$ \\
\hline \multirow{2}{*}{ Splitsko-dalmatinska } & Broj & 14.652 & 15.974 & 2.035 & 2.006 & 10.403 & 11.554 & 2.214 & 2.414 \\
\hline & $\%$ & $48 \%$ & $52 \%$ & $50 \%$ & $50 \%$ & $47 \%$ & $53 \%$ & $48 \%$ & $52 \%$ \\
\hline Šihensko-kninska & Broj & 2.831 & 3.029 & 290 & 277 & 2.113 & 2.275 & 428 & 477 \\
\hline sibensko-kninska & $\%$ & $48 \%$ & $52 \%$ & $51 \%$ & $49 \%$ & $48 \%$ & $52 \%$ & $47 \%$ & $53 \%$ \\
\hline Varaždinska & Broj & 6.965 & 7.943 & 120 & 108 & 6.117 & 7.128 & 728 & 707 \\
\hline & $\%$ & $47 \%$ & $53 \%$ & $53 \%$ & $47 \%$ & $46 \%$ & $54 \%$ & $51 \%$ & $49 \%$ \\
\hline Virovitičko-nodrayske & Broj & 1.820 & 1.942 & 110 & 128 & 1.475 & 1.537 & 235 & 277 \\
\hline 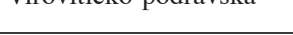 & $\%$ & $48 \%$ & $52 \%$ & $46 \%$ & $54 \%$ & $49 \%$ & $51 \%$ & $46 \%$ & $54 \%$ \\
\hline Vukovarsko-srijemska & Broj & 3.531 & 4.071 & 412 & 465 & 2.792 & 3.149 & 327 & 457 \\
\hline 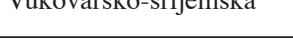 & $\%$ & $46 \%$ & $54 \%$ & $47 \%$ & $53 \%$ & $47 \%$ & $53 \%$ & $42 \%$ & $58 \%$ \\
\hline Zadarska & Broj & 3.918 & 4.181 & 401 & 355 & 2.922 & 3.155 & 595 & 671 \\
\hline Zadraska & $\%$ & $48 \%$ & $52 \%$ & $53 \%$ & $47 \%$ & $48 \%$ & $52 \%$ & $47 \%$ & $53 \%$ \\
\hline & Broj & 9.181 & 10.145 & 429 & 399 & 7.463 & 8.241 & 1.289 & 1.505 \\
\hline 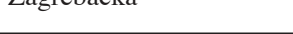 & $\%$ & $48 \%$ & $52 \%$ & $52 \%$ & $48 \%$ & $48 \%$ & $52 \%$ & $46 \%$ & $54 \%$ \\
\hline
\end{tabular}

Izvor: izrada autora. 
U tablici 5 prikazana je struktura osoba oboljelih od bolesti COVID-19 prema spolu na razini županija u cijelom promatranom razdoblju te za tri izdvojena razdoblja. U prvom razdoblju, najveći udio žena u ukupnom broju oboljelih od bolesti COVID-19 bio je u Koprivničko-križevačkoj županiji (59,40 \%), dok je najmanji bio u Međimurskoj županiji $(42,35 \%)$. U drugom razdoblju, od 1. listopada do 31. prosinca 2020. godine, najveći udio žena u ukupnom broju oboljelih od bolesti COVID-19 bio je u Međimurskoj županiji (54,52 \%), dok je najmanji bio u Dubrovačko-neretvanskoj županiji (49,71 \%). Naposljetku, u trećem razdoblju, od 1. siječnja do 25. veljače 2021. godine, najveći udio žena u ukupnom broju oboljelih od bolesti COVID-19 je u Vukovarsko-srijemskoj županiji (58,29 \%), dok je najmanji u Varaždinskoj županiji (49,27 \%). Generalno govoreći, udio muškaraca odnosno žena u broju oboljelih od bolesti COVID-19 nije se previše mijenjao kroz tri promatrana razdoblja.

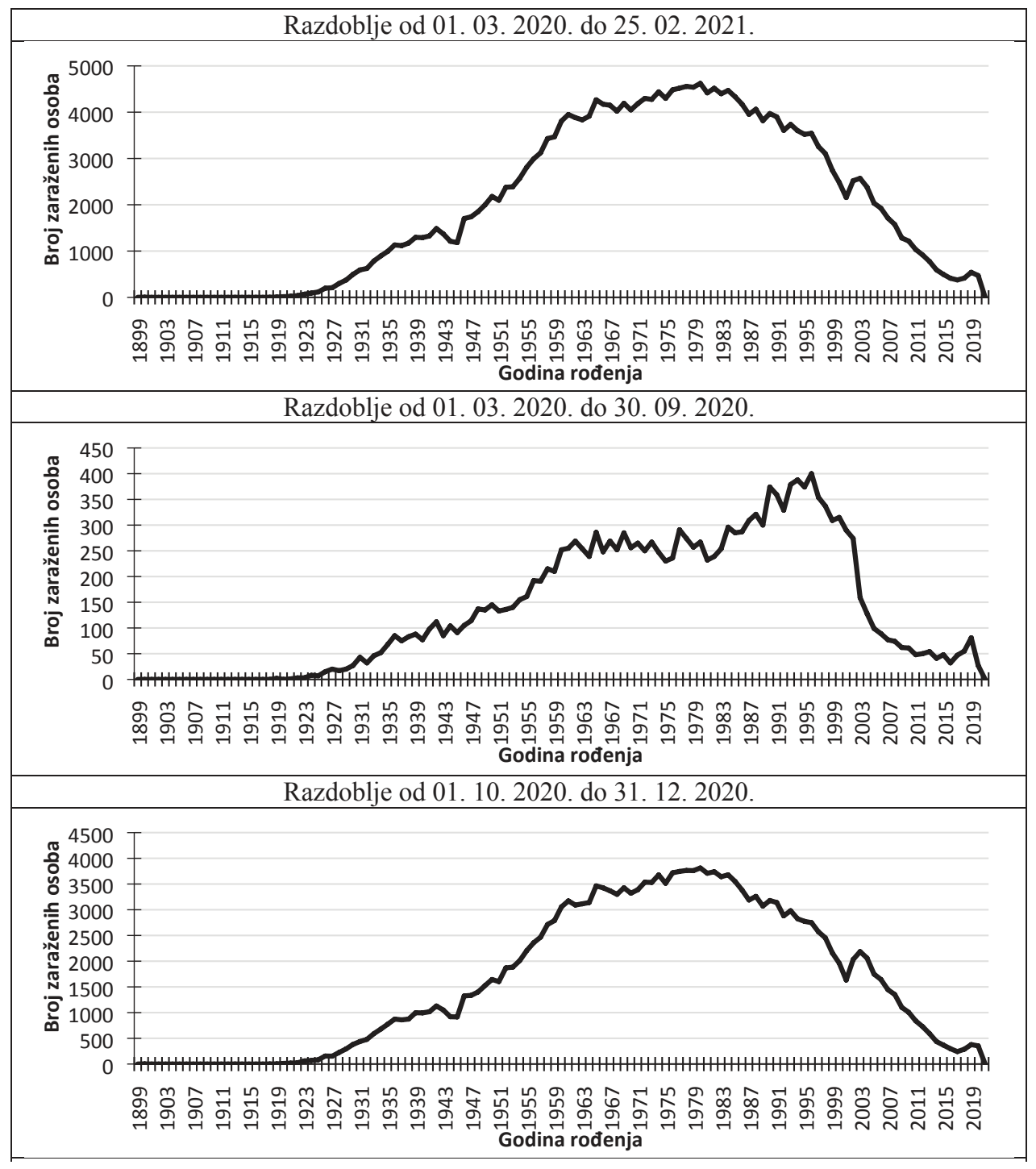




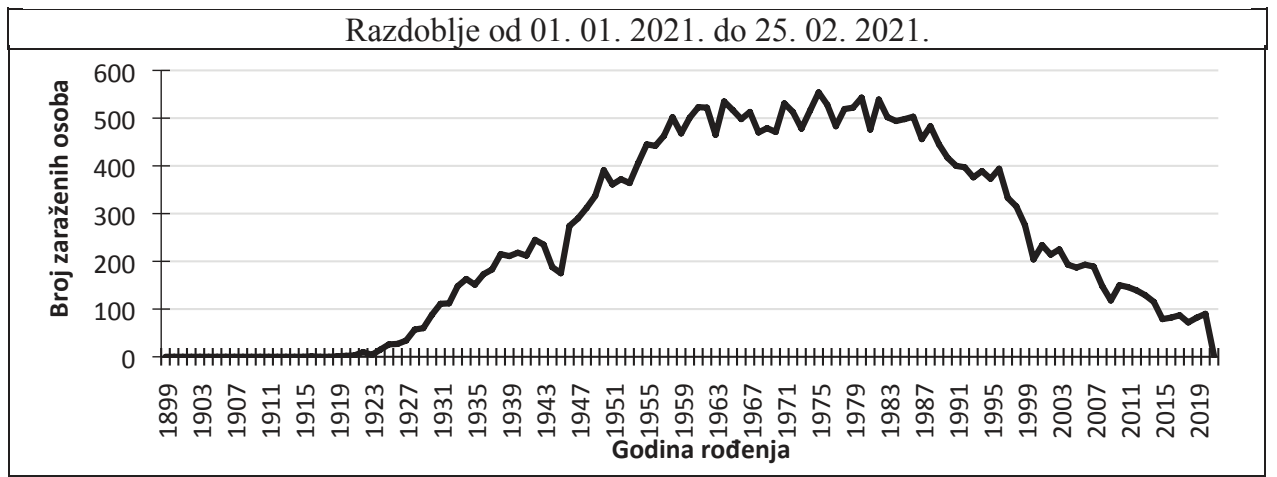

Slika 6. Broj osoba oboljelih od bolesti COVID-19 prema godini rođenja na razini Hrvatske, u razdoblju od 1. ožujka 2020. godine do 25. veljače 2021. godine

Izvor: izrada autora.

Na slici 6 prikazan je broj osoba oboljelih od bolesti COVID-19 prema godini rođenja na razini Hrvatske u cjelokupnom promatranom razdoblju, od 1. ožujka 2020. godine do 25. veljače 2021. godine, ali i tri izdvojena razdoblja. Prema slici 6 moguće je zaključiti da je najviše osoba oboljelih od bolesti COVID-19 bilo koje su rođene u 70 -im te početkom 80 -ih godina prošlog stoljeća.

Tablica 6. Prosječna i medijalna godina rođenja osoba oboljelih od bolesti COVID-19 na razini županija, u razdoblju od 1. ožujka 2020. godine do 25 . veljače 2021. godine

\begin{tabular}{|c|c|c|c|c|c|c|c|c|}
\hline \multirow{3}{*}{ Županija } & \multicolumn{8}{|c|}{ Razdoblie } \\
\hline & \multicolumn{2}{|c|}{$\begin{array}{l}\text { Od 01. 03. } 2020 \text {. } \\
\text { do 25. 02. } 2021 \text {. }\end{array}$} & \multicolumn{2}{|c|}{$\begin{array}{l}\text { Od } 01.03 .2020 . \\
\text { do } 30.09 .2020 .\end{array}$} & \multicolumn{2}{|c|}{$\begin{array}{l}\text { Od 01. 10.2020. } \\
\text { do 31. 12. } 2020 .\end{array}$} & \multicolumn{2}{|c|}{$\begin{array}{l}\text { Od 01. 01.2021. } \\
\text { do 25.02.2021. }\end{array}$} \\
\hline & Ar. sr. & Med. & Ar. sr. & Med. & Ar. sr. & Med. & Ar. sr. & Med. \\
\hline Bjelovarsko-bilogorska & 1973 & 1973 & 1979 & 1979 & 1973 & 1974 & 1967 & 1966 \\
\hline Brodsko-posavska & 1974 & 1974 & 1979 & 1982 & 1974 & 1974 & 1971 & 1970 \\
\hline Dubrovačko-neretvanska & 1977 & 1978 & 1976 & 1977 & 1976 & 1977 & 1980 & 1980 \\
\hline Grad Zagreb & 1976 & 1977 & 1979 & 1982 & 1976 & 1977 & 1972 & 1973 \\
\hline Istarska & 1976 & 1977 & 1975 & 1976 & 1977 & 1978 & 1973 & 1975 \\
\hline Karlovačka & 1974 & 1975 & 1977 & 1976 & 1974 & 1975 & 1974 & 1975 \\
\hline Koprivničko-križevačka & 1974 & 1975 & 1967 & 1968 & 1974 & 1976 & 1971 & 1971 \\
\hline Krapinsko-zagorska & 1976 & 1976 & 1976 & 1974 & 1976 & 1976 & 1974 & 1975 \\
\hline Ličko-senjska & 1973 & 1973 & 1977 & 1983 & 1973 & 1973 & 1973 & 1972 \\
\hline Međimurska & 1975 & 1976 & 1981 & 1984 & 1975 & 1976 & 1971 & 1971 \\
\hline Osječko-baranjska & 1974 & 1974 & 1975 & 1977 & 1974 & 1974 & 1971 & 1969 \\
\hline Požeško-slavonska & 1975 & 1975 & 1977 & 1977 & 1975 & 1976 & 1970 & 1969 \\
\hline Primorsko-goranska & 1975 & 1976 & 1972 & 1975 & 1976 & 1976 & 1973 & 1973 \\
\hline Sisačko-moslavačka & 1975 & 1975 & 1977 & 1979 & 1975 & 1976 & 1971 & 1971 \\
\hline Splitsko-dalmatinska & 1977 & 1978 & 1977 & 1980 & 1977 & 1978 & 1974 & 1974 \\
\hline Sibensko-kninska & 1974 & 1975 & 1979 & 1983 & 1974 & 1975 & 1972 & 1972 \\
\hline Varaždinska & 1975 & 1975 & 1978 & 1980 & 1975 & 1975 & 1973 & 1974 \\
\hline Virovitičko-podravska & 1975 & 1975 & 1982 & 1986 & 1975 & 1976 & 1971 & 1970 \\
\hline Vukovarsko-srijemska & 1973 & 1974 & 1975 & 1975 & 1973 & 1974 & 1971 & 1970 \\
\hline Zadarska & 1976 & 1977 & 1978 & 1982 & 1976 & 1978 & 1974 & 1975 \\
\hline Zagrebačka & 1976 & 1977 & 1979 & 1981 & 1976 & 1977 & 1973 & 1973 \\
\hline
\end{tabular}

Izvor: izrada autora. 
U tablici 6 prikazane su prosječne i medijalne vrijednosti godina rođenja oboljelih od bolesti COVID-19 na razini županija. Prema rezultatima iz tablice 6 uočava se da se, u značajnoj većini slučajeva, prosječna godina rođenja osoba oboljelih od bolesti COVID-19 na razini županija nalazi u 70-im godinama prošlog stoljeća. Dodatno, rezultati pokazuju da su vrijednosti medijana, u značajnoj većini slučajeva, veći od vrijednosti aritmetičkih sredina, ali za minimalni iznos, što upućuje na blago negativno asimetrične distribucije godina rođenja osoba oboljelih od bolesti COVID-19 na razini županija.

Prema dobivenim rezultatima moguće je zaključiti da postoji značajna varijabilnost u broju slučajeva bolesti COVID-19 u promatranom jednogodišnjem razdoblju. Analiza provedena po broju novoevidentiranih slučajeva bolesti COVID-19 u Hrvatskoj pokazala je da se nedjeljom redovito provodilo manje testiranja, što je posljedično rezultiralo s manjim brojem novoevidentiranih slučajeva bolesti COVID-19. Trendovi kretanja broja umrlih, izliječenih i broja aktivnih slučajeva bolesti slični su trendovima kretanja vezanim uz ukupan broj slučajeva bolesti COVID-19 te brojem novih slučajeva. Analiza pandemije bolesti COVID-19 po županijama u Hrvatskoj pokazala je da su najveće razine zaraženosti zabilježene u Gradu Zagrebu te u Splitsko-dalmatinskoj županiji, što je bilo i za očekivati jer su navedena područja najgušće naseljena i imaju najveći broj stanovnika, promatrano usporedno po pojedinačnim županijama. Vezano za analizu po spolu, može se zaključiti da je bolest COVID-19 otprilike jednako pogađala stanovništvo prema spolu, dok je najviše osoba oboljelih od bolesti COVID-19 bilo rođeno 70-ih godina te početkom 80 -ih godina prošlog stoljeća.

\section{ZAKLJUČAK}

U radu su promatrani trendovi u broju osoba oboljelih od bolesti COVID-19 na razini Republike Hrvatske te na razini županija. Dodatno je promatran i broj umrlih od bolesti COVID-19, broj aktivnih slučajeva te spol i godina rođenja zaraženih. Ovaj rad pruža izuzetno dobar temelj za daljnja statistička istraživanja vezana za promatrane COVID-19 varijable. Vrlo je važno adekvatno praćenje broja slučajeva i pravovremeno izvještavanje javnosti o stanju zaraženosti u Hrvatskoj. Značajan je utjecaj pandemije bolesti COVID-19 na sve društveno-ekonomske pokazatelje u zemlji poput bruto domaćeg proizvoda, cijena, sektora građevine i industrije, robne razmjene s inozemstvom, trgovine, transporta, turizma i uslužnih djelatnosti i dr., DZS (2021). Također se nalaže preispitivanje učinkovitosti određenih ekonomskih mjera i politika usmjerenih na zaštitu gospodarstva i društva u cjelini od javno-zdravstvene ugroze pandemije bolesti COVID-19 u Hrvatskoj. Pri tome je vrlo bitno pitanje zaposlenosti i očuvanja radnih mjesta. Ograničenje istraživanja vezano je uz nedostajuće podatke o broju slučajeva, spolu i godini rođenja zaraženih osoba na državnoj i županijskoj razini, odnosno ograničenja korištene baze podataka. Preporuke za daljnja istraživanja su povezati kretanja zaraženosti bolešću COVID-19 s utjecajem na pojedine sektore gospodarstva i ostala društveno-ekonomska kretanja kako bi se dale pravovremene smjernice za provođenje adekvatnih mjera ekonomske politike. 


\section{LITERATURA}

1. de Oliveira Lima, C. M. A. (2020). Information about the new coronavirus disease (COVID-19). Radiologia Brasileira, Vol. 53, No. 2, pp. V-VI. DOI: 10.1590/01003984.2020.53.2e1.

2. Deb, P., Furceri, D., Ostry, J. D., Tawk, N. (2020). The Economic Effects of COVID-19 Containment Measures. IMF Working Paper, No. 158, pp. 1-44.

3. del Rio, C., Collins, L. F., Malani, P. (2020). Long-term Health Consequences of COVID-19. JAMA, Vol. 324, No. 17, pp. 1723-1724. DOI: 10.1001/jama.2020.19719.

4. Državni zavod za statistiku (2021) Učinci pandemije bolesti COVID-19 na društveno-ekonomske pokazatelje. Dostupno na: https://www.dzs.hr/Hrv/Covid-19/pocetna. html (pristupljeno 3. ožujka 2021).

5. Fineberg, H. V. (2014). Pandemic Preparedness and Response - Lessons from the H1N1 Influenza of 2009. The New England Journal of Medicine, Vol. 370, No. 14, pp. 1335-1342. DOI: 10.1056/NEJMra1208802.

6. Forni, G., Mantovani, A. (2021). COVID-19 vaccines: where we stand and challenges ahead. Cell Death \& Differentiation, Vol. 28, pp. 626-639. DOI: 10.1038/s41418-02000720-9.

7. Hiscott, J., Alexandridi, M., Muscolini, M., Tassone, E., Palermo, E., Soultsioti, M., Zevini, A. (2020). The global impact of the coronavirus pandemic. Cytokine \& Growth Factor Reviews, Vol. 53, pp. 1-9. DOI: 10.1016/j.cytogfr.2020.05.010.

8. Janik, E., Bartos, M., Niemcewicz, M., Gorniak, L., Bijak, M. (2021). SARS-CoV-2: Outline, Prevention, and Decontamination. Pathogens, Vol. 10, No. 2, pp. 1-15. DOI: 10.3390/pathogens10020114.

9. Koronavirus.hr (2021a). Po danima županijama [online]. Dostupno na: https://www. koronavirus.hr/json/?action=po_danima_zupanijama (pristupljeno: 3. ožujka 2021).

10. Koronavirus.hr (2021b). Po osobama [online]. Dostupno na: https://www.koronavirus. $\mathrm{hr} /$ json/?action=po_osobama (pristupljeno: 3. ožujka 2021).

11. Koronavirus.hr (2021c). Podaci [online]. Dostupno na: https://www.koronavirus.hr/ json/?action=podaci (pristupljeno: 3. ožujka 2021).

12. Ministarstvo zdravstva (2020). Situacija s bolesti uzrokovanom novim koronavirusom COVID-19(SARS-CoV-2)25. veljače 2020. [online]. Dostupno na: https://zdravlje.gov. $\mathrm{hr} /$ UserDocsImages/2020\%20CORONAVIRUS/Situacija\%20s\%20novim\%20koronavirusom\%2026.2.2020-za-web.pdf (pristupljeno: 3. ožujka 2021).

13. Pal, M., Berhanu, G., Desalegn, C., Kandi, V. (2020). Severe Acute Respiratory Syndrome Coronavirus-2 (SARS-CoV-2): An Update. Cureus, Vol. 12, No. 3, DOI: 10.7759/cureus.7423.

14. Tadić, M. (2020). Utjecaj pandemija na gospodarstvo: Bazirano na primjeru globalne pandemije COVID-19 u Republici Hrvatskoj. Završni rad. Sveučilište u Splitu, Ekonomski fakultet, pp. 1-63. Dostupno na: https:/urn.nsk.hr/urn:nbn:hr:124:524668.

15. World Health Organization (2021a). Coronavirus: Symptoms [online]. Dostupno na: https://www.who.int/health-topics/coronavirus\#tab=tab_3 (pristupljeno 3. ožujka 2021). 
16. World Health Organization (2021b). Update on COVID-19 vaccine development [online]. Dostupno na: https://www.who.int/docs/default-source/coronaviruse/risk-comms-updates/update45-vaccines-developement.pdf?sfvrsn=13098bfc_5 (pristupljeno 3. ožujka 2021).

17. Wouters, O. J., Shadlen, K. C., Salcher-Konrad, M., Pollard, A. J., Larson, H. J., Teerawattananon, Y., Jit, M. (2021). Challenges in ensuring global access to COVID-19 vaccines: production, affordability, allocation, and deployment. The Lancet, online first, pp. 1-12. DOI: 10.1016/S0140-6736(21)00306-8.

18. Yuen, K. S., Ye, Z. W., Fung, S. Y., Chan, C. P., Jin, D. Y. (2020). SARS-CoV-2 and COVID-19: The most important research questions. Cell \& Bioscience, Vol. 10, No. 40, pp. 1-5. DOI: 10.1186/s13578-020-00404-4. 